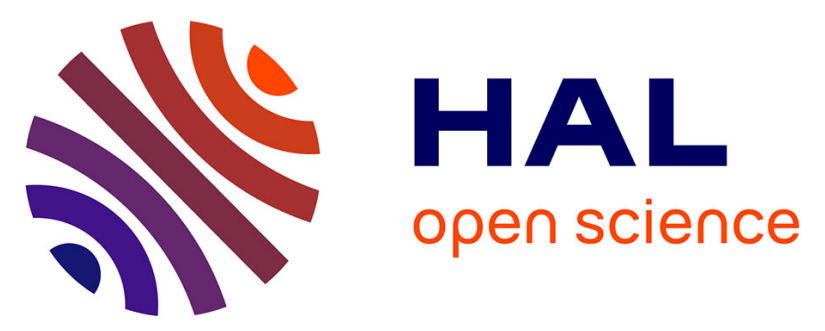

\title{
INFLUENCE OF LOADING RATE AND MODES ON INFILTRATION OF TREATED WASTEWATER IN SOIL-BASED CONSTRUCTED WETLAND
}

\author{
Sara Bisone, Mathieu Gautier, Matthieu Masson, Nicolas Forquet
}

\section{- To cite this version:}

Sara Bisone, Mathieu Gautier, Matthieu Masson, Nicolas Forquet. INFLUENCE OF LOADING RATE AND MODES ON INFILTRATION OF TREATED WASTEWATER IN SOIL-BASED CONSTRUCTED WETLAND. Environmental Technology, 2016, 6th International Symposium on Wetland Pollutant Dynamics and Control (WETPOL) and the Annual Conference of the Constructed Wetland Association, 38 (2), pp.163-174. 10.1080/09593330.2016.1185165 . hal-01328708

\section{HAL Id: hal-01328708 https://hal.science/hal-01328708}

Submitted on 8 Jun 2016

HAL is a multi-disciplinary open access archive for the deposit and dissemination of scientific research documents, whether they are published or not. The documents may come from teaching and research institutions in France or abroad, or from public or private research centers.
L'archive ouverte pluridisciplinaire HAL, est destinée au dépôt et à la diffusion de documents scientifiques de niveau recherche, publiés ou non, émanant des établissements d'enseignement et de recherche français ou étrangers, des laboratoires publics ou privés. 


\section{INFLUENCE OF LOADING RATE AND MODES ON INFILTRATION OF TREATED WASTEWATER IN SOIL- BASED CONSTRUCTED WETLAND}

Sara Bisone, Mathieu Gautier, Matthieu Masson, Nicolas Forquet $^{*}$

To cite this article:

Sara Bisone, Mathieu Gautier, Matthieu Masson \& Nicolas Forquet (2016): Influence of loading rate and modes on infiltration of treated wastewater in soil-based constructed wetland, Environmental Technology, 1-12, DOI: 10.1080/09593330.2016.1185165

To link to this article: http://dx.doi.org/10.1080/09593330.2016.1185165

Please contact the corresponding author $\left(^{*}\right)$ if you are interested by a copy of the article published in the journal. 


\title{
INFLUENCE OF LOADING RATE AND MODES ON INFILTRATION OF TREATED WASTEWATER IN SOIL-BASED CONSTRUCTED WETLAND
}

\author{
Sara Bisone ${ }^{1}$, Mathieu Gautier ${ }^{2}$, Matthieu Masson ${ }^{3}$, Nicolas Forquet ${ }^{4 *}$
}

${ }^{1}$ IRSTEA, UR MALY, 5, rue de la Doua, 69626 Villeurbanne Cedex, France.

Phone: 0033 472208629. E-mail: bisone.sara@ gmail.com

${ }^{2}$ Université de Lyon, INSA Lyon, DEEP, 69621 Villeurbanne Cedex, France.

Phone: 0033 472438348. E-mail: mathieu.gautier@insa-lyon.fr

${ }^{3}$ IRSTEA, UR MALY, 5, rue de la Doua, 69626 Villeurbanne Cedex, France.

Phone: 0033 472208758. E-mail: matthieu.masson@irstea.fr

${ }^{4}$ IRSTEA, UR MALY, 5, rue de la Doua, 69626 Villeurbanne Cedex, France.

Phone: 0033 472208772. E-mail: nicolas.forquet@irstea.fr

*Corresponding author

\section{Acknowledgement}

This work was supported by the ONEMA (Office national de l'eau et des milieux aquatiques). The authors would like to thanks C. Bertrand, J. Aubert, D. Coupet, C. Crétollier and V. Bourgeois for the installation of the pilot and technical support. They are also grateful to M. Arhror, C. BrosseQuilgars, S. Pelletant, L. Richard from Aquatic Chemistry Laboratory (LAMA, Irstea of Lyon) for chemical analysis and to R. Vera of diffractometry Centre of University Claude Bernard of Lyon. 


\section{Highlights}

- TWW infiltration test were performed on a technosol rich in clay

- Different loading rates and continuous vs intermittent loads were compared

- Intermittent load gave better result in term of infiltration performances

- This work underlined the importance of intermitted load on soil oxygenation

- Phosphate retention capacity of soil was studied 


\title{
INFLUENCE OF LOADING RATE AND MODES ON INFILTRATION OF TREATED WASTEWATER IN SOIL-BASED CONSTRUCTED WETLAND
}

\begin{abstract}
Over the last 10 years soil-based constructed wetlands for discharge of treated wastewater (TWW) are commonly presented as a valuable option to provide tertiary treatment. The uncomplete knowledge in soil modifications and a lack of clear design practices laid the foundation of this work. The aim of this study was to determine optimal hydraulic loads and to observe the main critical parameters affecting treating performances and hydraulic loads acceptance. For this purpose, a soil rich in clay and backfill was chosen to perform column infiltration tests with TWW. Two loading rates and two loading modes were compared to study the influence of an intermittent feeding. Inlet and outlet waters were periodically analysed and columns were instrumented with balances, tensiometers, $\mathrm{O}_{2}$ and temperature probes. Soil physico-chemical characteristics were also taken into account to better understand the modification of the soil. One of the main expectations of tertiary treatment is to improve phosphate removal. A particular attention was thus given to phosphorus retention. The interest of an intermittent feeding in presence of a soil with high clay content was showed. This study highlighted that an intermittent feeding could make possible the use of a clay rich soil for water infiltration.
\end{abstract}

\section{Keywords}

Constructed wetland, Wastewater infiltration, swelling clay, wastewater tertiary treatment, phosphate retention 


\section{Introduction}

Wastewater infiltration in soil is recognized as an effective and low-cost technique to improve effluent quality [1-4] and widely used to achieve tertiary treatment in onsite systems. [5-8] In that sense, soil-based constructed wetlands for discharge of treated wastewater (TWW) are currently seen as a valuable technique to reduce flow to surface receiving water bodies and to perform complementary treatments. The construction of these installations as buffer zone between the waste water treatment and the discharging area has rapidly grown in France: more than 500 constructed wetlands for discharge of TWW have been built over the last ten years. [9] However, a previous study showed no clear link between their design and aims. [9]

Despite the knowledge on soil water interaction in literature, forecasting soils acceptance of TWW loads only on the basis of their physico-chemical properties and hydrodynamic characteristics is still challenging. Site-planning and dimensioning are thus difficult, especially in the case of soilbased constructed wetlands for discharge of TWW. Indeed their construction is limited to the surrounding area of the treatment plant then soil cannot be chosen. Studying soil limits to accept TWW is therefore important to evaluate constructed wetlands effectiveness and to be able of design systems that ensure long-term performances.

This work rises from the necessity to understand soil capacity to accept TWW and treatment potential of a technosol close to a wastewater treatment plant in Bègles (France), where some experimental constructed wetlands pilots are ongoing. [10] This site is characterized by a high presence of backfill and clay.

Many studies tried to define the adaptability of soils to water infiltration and treatment considering renovation ability and drainage characteristics. [11,12] Permeability, cationic exchange capacity 
(CEC) as well as type and content of clay stand out as key factors. In particular, the high presence of clay is generally considered unfavourable and the practice of waste water infiltration not recommended. The constraint of TWW soil based constructed wetlands to be near the water treatment plant engenders the interest of studying soils with poorer characteristics. One of the aims of the study was to highlight the limits and potential of a technosol rich in clay and to determine how hydraulic design can influence their infiltration capacity.

Infiltration of large volumes of TWW in soils can modify soil structure and physico-chemical characteristics, [13] leading to a reduction of infiltration capacity, loss of soil water renovation capacity [14] and release of adsorbed contaminants. [15] Clogging is the most critical parameter. If a limited degree of clogging can enhance sorption, biodegradation and purification of pathogens, severe clogging can reduce the hydraulic capacity below the operational loading rate leading to anoxic soil conditions, and reduced purification. [2,16,17] Clogging is caused by a combination of different processes $[2,3,17-19]$ which can be divided in three categories: (1) physical processes due to particle setting and filtration of organic and inorganic suspended solids (SS) by the porous soil media and the subsequent superficial clogging; (2) chemical processes including precipitation of carbonates or clay swelling and dispersion; (3) biological processes such as accumulation and/or production of microbial cells or by-products such as extracellular polymeric substances.

Hydraulic conductivity (HC) of most soils is affected by swelling and dispersion of clay and aggregate failure. [20] Both soil characteristics and water quality influence the rapidity and importance of $\mathrm{HC}$ decrease. [21] It is known that sodium (Na) can significantly affect soil properties weakening the bonds of clay particles when the soil is moistened, resulting in clay swelling and dispersion. Clay mineralogy is as important as clay content since $\mathrm{Na}$ and potassium (K) affinity can vary between clays. Buelow et al. [21] compared the effect of the same effluent 
rich in $\mathrm{Na}$ on different soils and found out that $\mathrm{HC}$ decrease on soils rich in montmorillonite and vermiculite was higher than in kaolinite dominated soil.

Regarding treatment performances, phosphorus (P) is one of the target elements for tertiary treatment and soil is known to provide $\mathrm{P}$ retention. Different processes are involved. $\mathrm{P}$ can be sorbed by ferric and aluminium oxides or hydroxides, as well as carbonate minerals or precipitated with iron, calcium or aluminium ions. $[3,22,23] \mathrm{P}$ retention on clay by anion exchange has also been documented. [24] Clay may adsorb anions by electrostatic interaction, exchanging structural $\mathrm{OH}^{-}$groups or by accompanying multivalent cations at exchange positions. Soil mineralogy is then determinant in $\mathrm{P}$ retention but water characteristics and environment conditions also play an important role [25] showed that solutions with higher concentrations of calcium can enhance P precipitation. Redox potential and $\mathrm{pH}$ influence $\mathrm{P}$ retention and desorption. [26-29] In general, for alkaline conditions $\mathrm{P}$ sorption is mainly due to precipitation with $\mathrm{Ca}$, while in acid conditions adsorption on aluminium and iron will be prevalent. [22]

This paper presents a column experiment to observe the interactions of Bègles soil with TWW and to determine optimal hydraulic loading to design on site experiments. The influence of two loading rates and two loading modes was studied in term of $\mathrm{HC}$ and ponding occurrence in repacked columns. In addition, chemical analyses were performed on inlet and outlet waters to better understand soil behaviour notably in term of retention of pollutants and dissolution of phases. A focus was done on P retention performances to evaluate the effect of wetting drying cycles. Besides, phosphate retention capacity of the soil was estimated. 


\section{Materials and methods}

\subsection{Soil sampling and analysis}

Soil was collected near the wastewater treatment plant located in Bègles (France). This soil can be defined as a technosol according to World Reference Base for Soil Resources. [30] In order to take into account soil heterogeneity, four aligned pits were excavated $40 \mathrm{~m}$ away from each other. The extracted soil was mixed to obtain a homogeneous material for column packing.

\subsubsection{Physical-chemical characterization}

Grain size distribution was determined on a mass basis by the pipette method after limestone extraction (French Standard NF X31-107). Limestone was measured following the French standard (NF ISO 10693) and organic carbon by sulfochromic oxidation as described by NF ISO 14235.

Soil $\mathrm{pH}$ and electric conductivity (EC) were measured in a water/soil ratio of $5(\mathrm{w} / \mathrm{w})$ after a contact period of 30 minutes (pH probe Sentix-41, EC probe KLE 325, WTW).

Concentrations of majors ( $\mathrm{Si}, \mathrm{Fe}, \mathrm{Al}, \mathrm{Na}, \mathrm{Mn}, \mathrm{Mg}, \mathrm{K}, \mathrm{Ti}$ ) and trace elements (As, $\mathrm{Ba}, \mathrm{Cd}, \mathrm{Cr}, \mathrm{Cu}$, $\mathrm{Ni}, \mathrm{Pb}, \mathrm{Zn}$ ) were measured, after digestion by $\mathrm{LiBO}_{2}$ fusion, by ICP-OES for major and ICP-MS for trace elements. Organic carbon was analysed after separation by a CS analyser.

CEC and extractable cations were measured by Metson method using $1 \mathrm{M}$ ammonium acetate $\left(\mathrm{NH}_{4} \mathrm{OAc}\right)$ at $\mathrm{pH} 7$, as described in French Standard NF X31-130. Cations $\left(\mathrm{Na}^{+}, \mathrm{K}^{+}, \mathrm{Mg}^{2+}, \mathrm{Ca}^{2+}\right)$ were quantified by ICP-OES and ammonium by spectrophotometry with Berthelot reaction (French standard T 90-015-2 (2000)). Extracted cations concentrations were used to calculate exchangeable sodium percentage (ESP) and exchangeable potassium percentage (EPP): 


$$
\begin{aligned}
& E S P=\frac{N a^{+}}{N a^{+}+K^{+}+C a^{2+}+M g^{2+}} \cdot 100 \\
& E P P=\frac{K^{+}}{N a^{+}+K^{+}+C a^{2+}+M g^{2+}} \cdot 100
\end{aligned}
$$

where cations concentrations are expressed in meq·for $100 \mathrm{~g}$ of soil.

Phosphorus retention capacity of the soil was estimated by equilibrium isotherm experiments. This method enables the calculation of the theoretical maximum $\mathrm{P}$ sorption value for a substrate. Approximately $10 \mathrm{~g}$ of soil were placed in contact with $100 \mathrm{~mL}$ of solution containing different

concentrations of $\mathrm{P}\left(1,5,10,25,50,100 \mathrm{mg} \cdot \mathrm{L}^{-1}\right.$ of $\left.\mathrm{P}\right)$ for $24 \mathrm{~h}$. Solutions were prepared with a buffer of potassium dihydrogen phosphate and dipotassium hydrogen phosphate $\left(\mathrm{KH}_{2} \mathrm{PO}_{4} / \mathrm{K}_{2} \mathrm{HPO}_{4}\right)$ to obtain a $\mathrm{pH}$ of 8 (equivalent to the natural soil $\mathrm{pH}$ ). Apparent $\mathrm{P}$ sorption capacity of the soil was estimated using the linear form of the Langmuir equation. [25]

Once column infiltration test completed, total phosphorus was analysed at different depths of one of the columns to quantify phosphorous retained. For this purpose, soil samples were mineralized with aqua regia $\left(\mathrm{HNO}_{3} / \mathrm{HCl}\right)$ by microwave digestion (French Standard EN 13346).

\subsubsection{Mineralogical characterization}

A soil sample of fraction $<2 \mathrm{~mm}$ grounded to powder $(<50 \mu \mathrm{m})$ was first analysed by X-ray diffraction (XRD). Clay fraction was then extracted from the soil to identify clay mineralogy. [31] The presence of calcium carbonate been poor, it was not necessary to treat the samples with acid before. The procedure of clay identification involves a series of sample treatments: orientated air dried clay; orientated glycolated by ethylene glycol; orientated heated at $400^{\circ} \mathrm{C}$; heated at $550^{\circ} \mathrm{C}$ and disorientated. [31] Every preparation was analysed by XRD. The comparison between all spectrums enabled the identification of different clays present in the sample, particularly the 
presence of swelling clays. A Bruker D8 Advance instrument equipped with a Position Sensitive Detector VÅNTEC-1 "SUPER SPEED" was used. The samples were scanned on an angular range from $1^{\circ}$ to $30^{\circ}$ with a step of $0.022^{\circ}$ for a total time of 11 minutes. Result processing was performed with the DIFFRAC.EVA ${ }^{\odot}$ software (V3.0) using the Powder Diffraction File database distributed by the International Centre for Diffraction Data.

\subsection{Soil column experiment}

\subsubsection{Column packing and setup}

The soil column infiltration test was performed inside an experimental hall near a wastewater treatment plant in Villeurbanne (France). Three Plexiglas columns, $36 \mathrm{~cm}$ in diameter, were filled with $54 \pm 0.5 \mathrm{~cm}$ of the disturbed soil. Before column packing, soil was sieved at $3.5 \mathrm{~cm}$ and coarser gravel excluded to limit lateral flow and insure better media homogeneity. To determine gravel fraction of soil in column, a sample of about $8 \mathrm{~kg}$ of soil was sieved at $2 \mathrm{~mm}$ and $10 \mathrm{~mm}$.

Various packing methods were found in the literature [32]. Slurry packing was selected since Lewis and Sjöstrom [33] demonstrated that this method best suited for large column experiments. Columns were filled adding small increments $(1-2 \mathrm{~cm})$ of soil into the columns while saturating the soil by an upward flow with tap water to help soil settle. Once filled, columns were drained and collected water analysed. The final bulk density of the packed soil varied between 1.45 and 1.48 $\mathrm{g} \cdot \mathrm{cm}^{-3}$.

At the column basis, a porous plate (UMS leachate sampler KL2-1200) was connected to an external overflow device to settle the hydraulic head. The hydraulic head was kept $20 \mathrm{~cm}$ below the porous plate for the entire experiment. Each column was equipped of two PT100 probes to measure the inside temperature and five fiber-optic oxygen Dipping Probe (DP-PSt3) for in-line 
measurement (PreSens GmbH). Oxygen optical probes measure oxygen content in both water and air phases. [34,35] The basis of this type of measurement is the fluorescence extinction of a complex fixed in sol-gel when exposed to oxygen. Two columns were also equipped of three tensiometers (UMS Pressure Transducer Tensiometer - T5). Column design and probes placement is presented in Fig. 1.

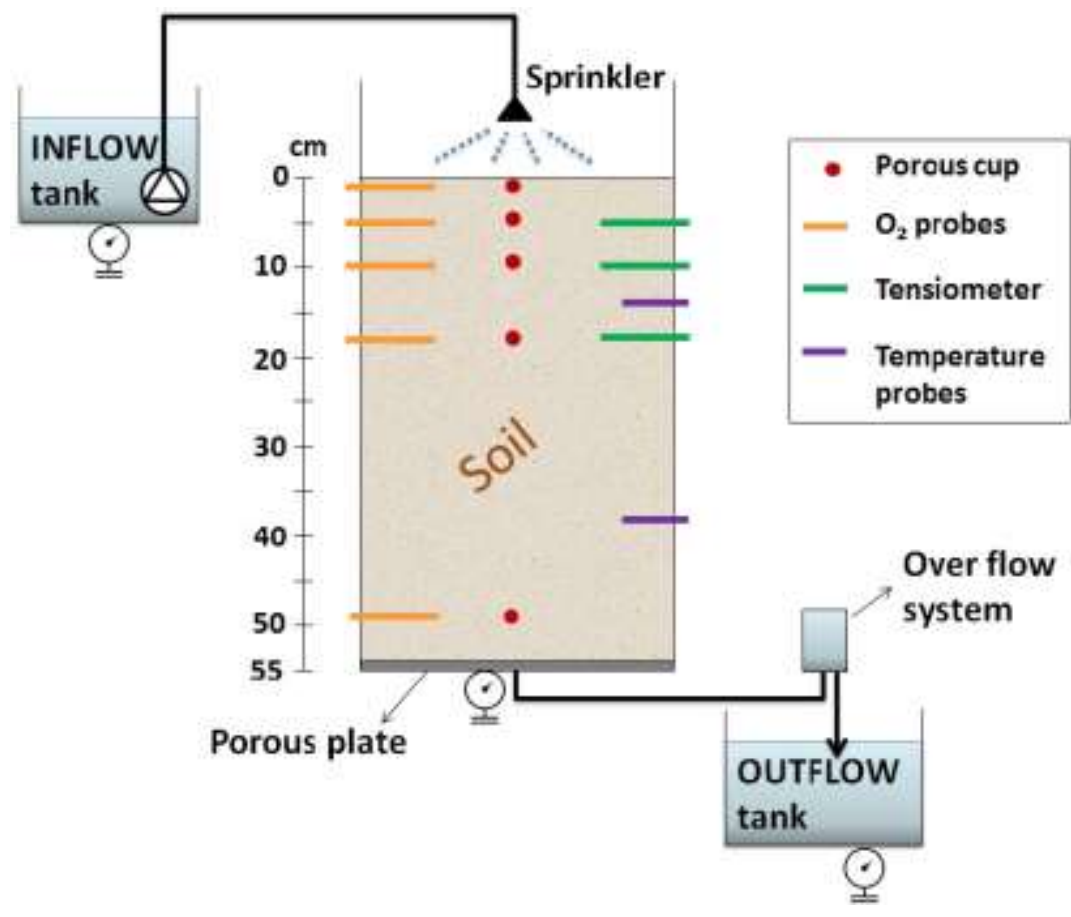

Fig. 1. Sketch of column-setup and sensors placement.

For each column, TWW was daily collected in an influent tank, from where it was pumped by a diaphragm pump (Iwaki, LK-series) to the top of the column. Water was then distributed on the surface of the column by a sprinkler (tangential sprinkler, BETE). Outflow water, collected from the porous plate, reached an effluent tank.

Influent and effluent tank masses were monitored using scales (NOBEL, France) (balance range 1 $-60 \mathrm{~kg}$ ). Columns masses were also monitored with scales ranging from 50 to $300 \mathrm{~kg}$. Uncertainty on weight was below $0.05 \%$. 
Excluding oxygen probes, which had their specific recording device; all data were recorded every minute using a data logger (IDL 100 Gantner Instrument, Austria).

\subsubsection{Experimental design}

Three columns were run in parallel to compare two hydraulic loading rates and two loading modes (continuous and intermittent). Initial hydraulic loads were chosen on the basis of the field saturated $\mathrm{HC}\left(\mathrm{K}_{\mathrm{fs}}\right)$ of the soil $\left(50 \mathrm{~mm} \cdot \mathrm{h}^{-1}\right)$ measured by Porchet method. Maximum loading rate was equivalent of $1 / 10$ of the $K_{\mathrm{fs}}$ and minimum loading rate to the half ( $1 / 20$ of the $\left.K_{\mathrm{fs}}\right)$. In the discussion the following abbreviations will be used: 2 for intermittent column with maximum loading; C2 for continuous column with the same loading rate to evaluate the effect of the loading mode; I1 for intermittent column with lower loading rate. The initial loading rate for the continuous column (C2) was fixed at $0.12 \cdot \mathrm{m}^{3} \cdot \mathrm{m}^{-2} \cdot \mathrm{d}^{-1}$. Therefore intermittent columns received $0.18 \mathrm{~m}^{3} \cdot \mathrm{m}^{-2} \cdot \mathrm{d}^{-1}$ (column I1) and $0.36 \mathrm{~m}^{3} \cdot \mathrm{m}^{-2} \cdot \mathrm{d}^{-1}$ (column I2) during feeding periods. Intermittent cadence was initially chosen on the basis of typical constructed wetland design: columns were loaded for 3 days and $1 / 2$ followed by a rest period of 7 days. [36]

\subsubsection{Saturated HC}

The saturated $\mathrm{HC}$ of the three columns were estimated when a permanent ponding was present as following:

$$
H C=\frac{Q}{A t} \times \frac{l}{l+h_{p}+h_{h}}
$$

where $Q / t$ is the outflow $\left(\mathrm{cm}^{3} \cdot \mathrm{min}^{-1}\right), A$ the surface of the column $\left(\mathrm{cm}^{2}\right), l$ column length $(\mathrm{cm}), h_{p}$ ponding height $(\mathrm{cm})$ and $h_{h}$ the distance between porous plate and overflow system. For this purpose, the outflow was calculated thanks to column scales on a minute basis. 


\subsubsection{Water sampling and analysis}

Influent water was sampled and analysed once a week. The effluent sampling frequency was adjusted over time in order to account for the transient phenomena occurring at the beginning of the experiment. Water samples were analysed for total organic carbon (TOC), dissolved organic carbon (DOC), majors cation $\left(\mathrm{Ca}^{2+}, \mathrm{Mg}^{2+}, \mathrm{Na}^{+}, \mathrm{K}^{+}, \mathrm{NH}_{4}{ }^{+}\right)$major anions $\left(\mathrm{Cl}^{-}, \mathrm{SO}_{4}{ }^{2-}, \mathrm{PO}_{4}{ }^{3-}, \mathrm{NO}_{3}{ }^{-}\right.$, $\mathrm{NO}_{2}{ }^{-}$) total nitrogen (Ntot) and total Kjeldahl nitrogen (TKN). Suspended solids (SS) and $\mathrm{HCO}_{3}{ }^{-}$ were also quantified in influent water. European standard methods were used for analysis (NF EN 872, EN ISO 10304-1, NF EN ISO 14911, NF EN 25663, NF EN 6878, NF EN ISO 9963-1). pH and EC were measured at the same time as sampling.

The tendency of water to decrease HC is usually evaluated by sodium adsorption ratio (SAR) and water salinity (indirectly measured through electrical conductivity). Adjusted sodium absorption ratio $\left(\mathrm{SAR}_{\mathrm{adj}}\right)$ [37] according to the equation proposed by Asano at al. [37]:

$$
S A R_{a d j}=\frac{\left[\mathrm{Na}^{+}\right]}{\sqrt{\left[\mathrm{Ca}_{x}^{2+}\right]+\left[\mathrm{Mg}^{2+}\right] / 2}}
$$

As sodium, potassium can accelerate soil hydraulic properties deterioration. Similarly to SAR its role can be evaluated with the potassium adsorption ratio (PAR):

$$
P A R=\frac{\left[K^{+}\right]}{\sqrt{\left[C a^{2+}\right]+\left[\mathrm{Mg}^{2+}\right] / 2}}
$$

Biomass development is a key factor for soil clogging. Degradability of organic matter was taken into account including estimation of aromatic structure of DOC with the parameter SUVA (specific

ultraviolet light absorbance). [38] SUVA was calculated as ratio between UV-Absorbance at 254 $\mathrm{nm}$ measurements of the samples and their DOC concentration $\left(\mathrm{mg} \cdot \mathrm{L}^{-1}\right)$. 


$$
S U V A=\frac{A b s_{254}}{[D O C]} \times 100
$$

\section{Results and discussion}

\subsection{Soil characterization}

The major physicochemical characteristics and the elemental total contents of the studied soil are summarized in 
Table 1. 
Table 1. Physicochemical characteristics and elemental total contents of the soil (fraction $<2 \mathrm{~mm}$ ).

\begin{tabular}{ll}
\hline $\mathrm{pH}\left(\mathrm{H}_{2} \mathrm{O}\right)$ & $8.0 \pm 0.1$ \\
$\mathrm{EC}\left(\mu \mathrm{S} \cdot \mathrm{cm}^{-1}\right)$ & $320 \pm 10$ \\
$\mathrm{CEC}(\mathrm{meq} / 100 \mathrm{~g})$ & $15 \pm 2$ \\
$\mathrm{ESP}(\%)$ & $2.7 \pm 0.1$ \\
$\mathrm{EPP}(\%)$ & $1.6 \pm 0.1$ \\
$\mathrm{C}_{\text {tot }}(\%)$ & $1.0 \pm 0.01$ \\
$\mathrm{C}_{\text {org }}(\%)$ & $0.61 \pm 0.03$ \\
$\mathrm{CaCO}_{3}(\%)$ & $2.2 \pm 0.1$ \\
$\mathrm{SiO}_{2}(\%)$ & $72.7 \pm 0.7$ \\
$\mathrm{Fe}_{2} \mathrm{O}_{3}(\%)$ & $3.2 \pm 0.1$ \\
$\mathrm{Al}_{2} \mathrm{O}_{3}(\%)$ & $8.5 \pm 0.1$ \\
$\mathrm{CaO}(\%)$ & $4.2 \pm 0.2$ \\
$\mathrm{Na} \mathrm{O}_{2}(\%)$ & $0.48 \pm 0.02$ \\
$\mathrm{MnO}(\%)$ & $0.048 \pm 0.01$ \\
$\mathrm{MgO}(\%)$ & $0.80 \pm 0.08$ \\
$\mathrm{~K}_{2} \mathrm{O}(\%)$ & $1.5 \pm 0.1$ \\
$\mathrm{TiO}(\%)$ & $0.41 \pm 0.04$ \\
$\mathrm{P}_{2} \mathrm{O}(\%)$ & $0.13 \pm 0.01$ \\
$\mathrm{As}\left(\mathrm{mg} \cdot \mathrm{kg}^{-1}\right)$ & $13 \pm 1$ \\
$\mathrm{Ba}\left(\mathrm{mg} \cdot \mathrm{kg}^{-1}\right)$ & $255 \pm 13$ \\
$\mathrm{Cd}\left(\mathrm{mg} \cdot \mathrm{kg}^{-1}\right)$ & $8.8 \pm 1.3$ \\
$\mathrm{Cr}\left(\mathrm{mg} \cdot \mathrm{kg}^{-1}\right)$ & $65 \pm 3$ \\
$\mathrm{Cu}\left(\mathrm{mg} \cdot \mathrm{kg}^{-1}\right)$ & $33 \pm 3$ \\
$\mathrm{Ni}\left(\mathrm{mg} \cdot \mathrm{kg}^{-1}\right)$ & $45 \pm 5$ \\
$\mathrm{~Pb}\left(\mathrm{mg} \cdot \mathrm{kg}^{-1}\right)$ & $32 \pm 2$ \\
$\mathrm{Zn}\left(\mathrm{mg} \cdot \mathrm{kg}^{-1}\right)$ & $89 \pm 9$ \\
\hline
\end{tabular}

The soil is mainly composed by silicate minerals and has a low concentration of calcium carbonate. The high concentration of trace elements (especially As, $\mathrm{Cd}$ and $\mathrm{Ba}$ ) could be attributed to the presence of backfill, essentially building materials. Technosol rich in backfill commonly have low nutrients concentrations. [30] In the studied soil low organic matter concentrations were observed. Relevant concentrations of $\mathrm{Al}_{2} \mathrm{O}_{3}, \mathrm{Fe}_{2} \mathrm{O}_{3}$ and $\mathrm{Ca}$ were observed. These elements may contribute to the phosphorus retention. The prevalence of a mechanism of retention (for example adsorption on $\mathrm{Al}$ or Fe hydroxides/oxides or precipitation with $\mathrm{Ca}$ ) will be determined by the physico-chemicals conditions and the accessibility of adsorption sites. 
The soil studied is characterized by a high CEC (15 meq/100g) and low ESP (2.7 \%) and EPP (1.6 $\%$ ), which suggests a high ability for effluent renovation without major soil structure breakdown risk. Indeed, high CEC indicates the possibility of cation exchange and hence of clay swelling or dispersion. On the other end, the ratio between divalent and monovalent cations (ESP and EPP) is also important to determine the likelihood of exchange leading to aggregate stability reduction. Van de Graaff and Patterson [39] notably stated that soils having more than 6\% ESP are considered to have structural stability problems. Moreover, if soils with high permeability and low CEC insure a lower risk of clogging and hydraulic failure, they did not provide sufficient attenuation of effluent pollutants. Carroll et al. [11] reported that soils with initial medium or high CEC and moderate permeability are the most suitable for water renovation.

Grain size distribution of fraction $<2 \mathrm{~mm}$ is presented in Table 2; following the American soil classification system, soil texture can be classified as a sandy clay loam.

Table 2. Grain size distribution of fraction $<2 \mathrm{~mm}$ (mean and standard deviation). Results are expressed in term of mass percentage of the soil fraction $<2 \mathrm{~mm}$.

\begin{tabular}{ccc}
\hline Grain size fraction $(\mathbf{m m})$ & \multicolumn{2}{c}{$(\%$ mean $\mathbf{~ S D})$} \\
\hline$<0.002$ & 21.7 & \pm 3.0 \\
$0.002-0.005$ & 15.1 & \pm 2.0 \\
$0.005-0.02$ & 11.3 & \pm 1.2 \\
$0.02-0.2$ & 5.2 & \pm 0.6 \\
$0.2-2$ & 46.7 & \pm 4.4 \\
\hline
\end{tabular}

Clay content is one of the key parameters normally considered to evaluate the suitability of a soil for water infiltration. Abel et al. [40] notably report that for soil aquifer treatment it is normally recommended to avoid clay soil due to their relative impermeability that leads to high-land requirements for percolation ponds. The concentration of clay can thus affect HC especially the 
presence of swelling clay. Determine clay mineralogy was therefore the next step to determine the risk of infiltration decrease of this soil.

Even if soils texture is classified on the basis of grain size distribution of fraction $<2 \mathrm{~mm}$, the percentage of gravels can influence the hydraulic behaviour of a soil. The site studied is characterized by a high heterogeneity especially in term of backfill abundance. To ensure the homogeneity of the material used in the experiment the four samples were mixed and sieved at 35 $\mathrm{mm}$ and the $>35 \mathrm{~mm}$ fraction was rejected. Soil fraction $2-35 \mathrm{~mm}$ amounted for $34 \%(\mathrm{w} / \mathrm{w})$ of the retained fraction. Therefore in column experiment clays represent $14.3 \%$ of the total mass.

XRD analyses performed on disoriented powder of the soil fraction $<2 \mathrm{~mm}$ indicated the presence of quartz, calcium carbonate and clays. These results are in agreement with the high presence of $\mathrm{SiO}_{2}$ highlighted by total content analysis. As seen with chemical analysis $\mathrm{CaCO}_{3}$ content was low .

Clays were then extracted and analysed for identification. Fig. 2 shows the spectrum of four different preparations of the same clay sample (untreated, glycolated, heated at $400^{\circ} \mathrm{C}$ and heated at $550^{\circ} \mathrm{C}$ ). The spectrum of the untreated sample (blue line) shows a pick at $\mathrm{d}=14 \AA$ (label 1 on the figure), which shift to about $17 \AA$ after glycol addition (green line), due to expansion of sheets. This peak loses in intensity and moves at $10 \AA$ after heating (red and purple line). This pattern is typical of swelling clay and can be attributed to montmorillonite, a common clay in soils of temperate regions. Montmorillonite was also characterized by a high CEC due to isomorphous substitutions of cations. Montmorillonite was estimated to amount for about $50 \%$ of the clay fraction. Thanks to the comparison between the four spectra with specific preparations, illite, chlorite group clays and kaolinite (as dickite) were also identified. For example the loss of the peak near $7 \AA$ (label 2 in the figure) and the pick at $3.6 \AA$ (label 3 in the figure) after heating at $500^{\circ} \mathrm{C}$ enabled the identification of kaolinite. The identification was completed using the information of 
the disoriented clays analysis, non-presented in the figure. Illite is a 2:1 clay, chlorite is a group of 2:1:1 clays that can be differentiated on the basis of metals substitution in their structure and kaolinite is a 1:1 clay. [41] All three are non-swelling clays.

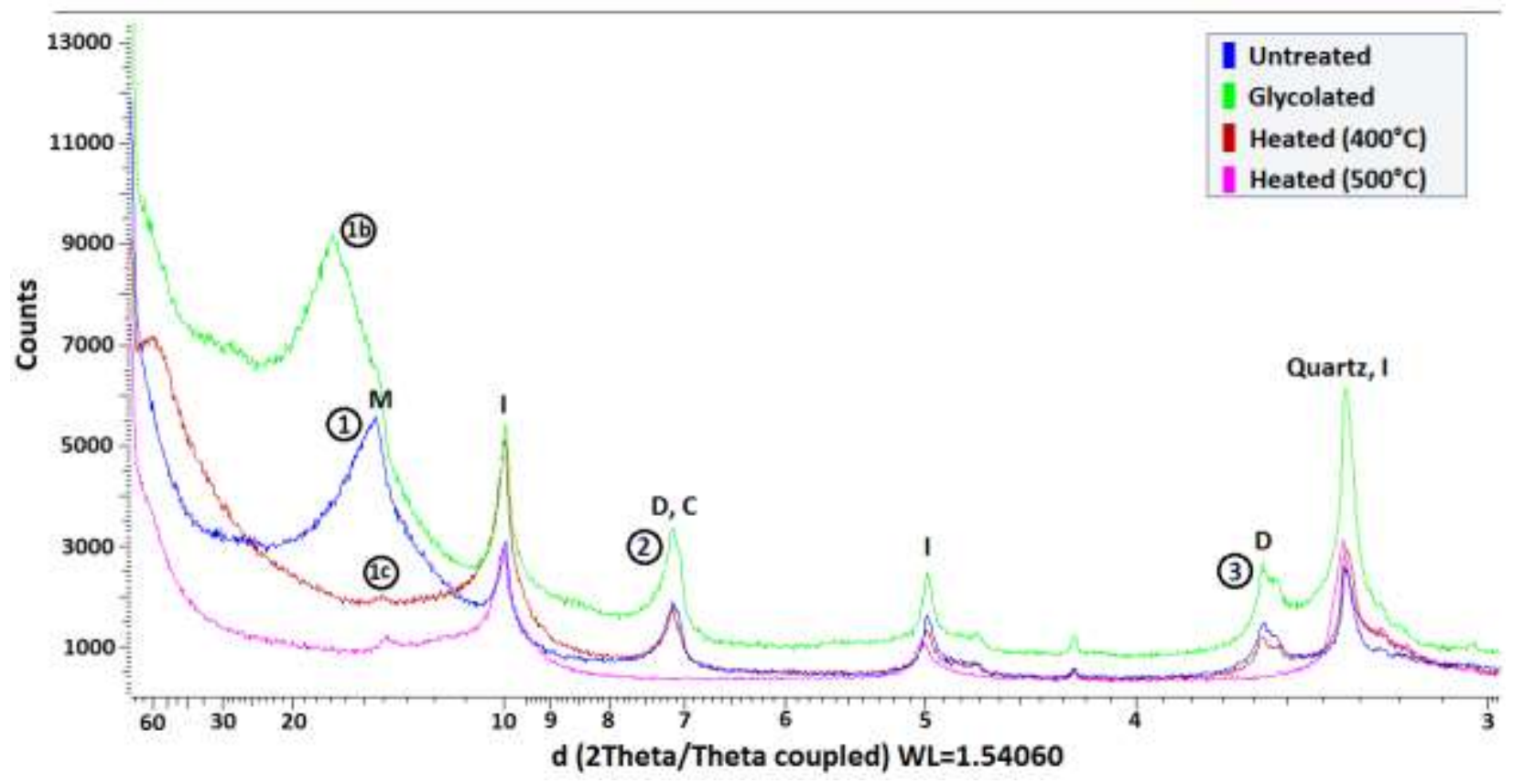

Fig. 2. XRD diffraction spectrum analysis for the four preparations of oriented clay (untreated, glycolated, heated at $400^{\circ} \mathrm{C}$ and heated at $550^{\circ} \mathrm{C}$ ). With peak identification corresponding to Montmorillonite $(M)$, Dikite (D), Illite (I), Chlorite (C).

The high presence of expansive clay can obviously be a barrier in wastewater infiltration by decreasing soil porosity. For example, Aksu et al. [42] compared the volume increase of kaolinite and montmorillonite effect of saturation of the media with distilled water. They observed a $39 \%$ volume increase of montmorillonite and $15 \%$ volume increase for kaolinite.

Clay swelling and dispersion can be reinforced by the cation exchange, consequence of effluent infiltration. Considering CEC and ESP/EPP measured the substitutions between monovalent cations and $\mathrm{Ca}^{2+}$ are in all likelihood favoured. Residual ammonium in treated wastewater can also 
be retained by montmorillonite by ion exchange and lead to a modification of hydraulic properties. [43]

Treatment performances and contaminant retention would also be influenced by the presence of clay and by their mineralogy. If high content of clay in a soil can restrain its utilization for infiltration purpose, their ability to retain contaminants can make them valuable as a polishing treatment. In addition to ammonium adsorption, clay can sorb phosphate by ionic exchange. [24,44]

\subsection{TWW infiltration tests}

\subsubsection{Hydraulic behaviour}

Infiltration tests were started on the three columns at the same time. Permanent ponding was rapidly reached on continuous column $(\mathrm{C} 2)$ (after a cumulative load of $1.8 \mathrm{~m}^{3} \cdot \mathrm{m}^{-2}$ ). The height of ponding forced to interrupt feeding three times, and finally completely stop it after 58 days and a cumulative hydraulic load of about $10 \mathrm{~m}^{3} \cdot \mathrm{m}^{-2}$. Intermittent columns (I1 and I2) accepted higher cumulative hydraulic loads (Fig. 3).

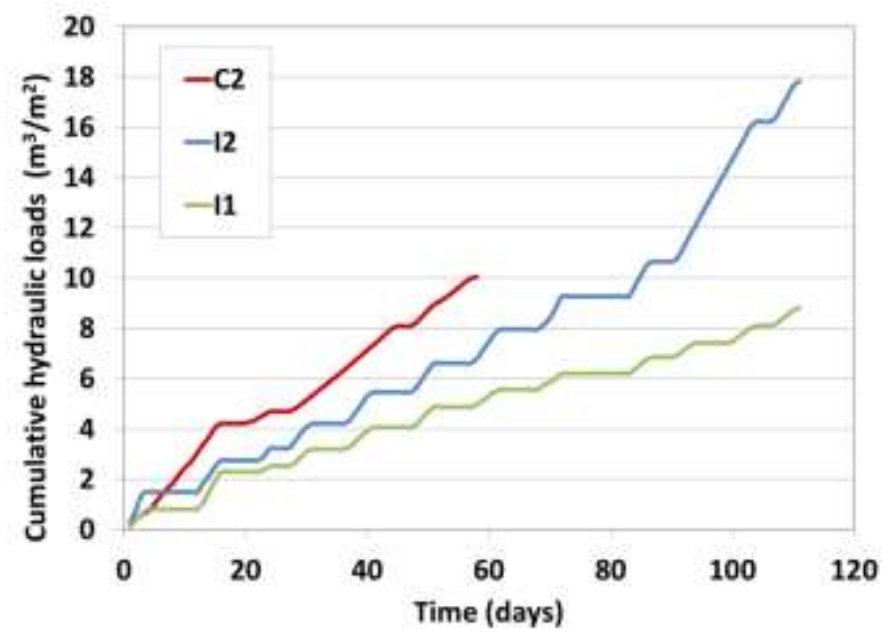

Fig. 3. Cumulative hydraulic load for the three columns $(C 2, I 1, I 2)$ 
In Fig. 4 the average daily values are reported. $\mathrm{HC}$ tend to decrease over time for all columns with the same trend. However ponding incidence was not the same for all columns. It normally occurred at the last day of feeding for intermittent columns while, in absence of rest period, it became permanent on C2. Despite a similar trend in $\mathrm{HC}$ at saturation, the continuously-fed column could not be operated as long as intermittently-fed ones, therefore the cumulative hydraulic loads accepted were higher for intermittently-fed columns than for the continuously-fed one as shown in Fig. 3.

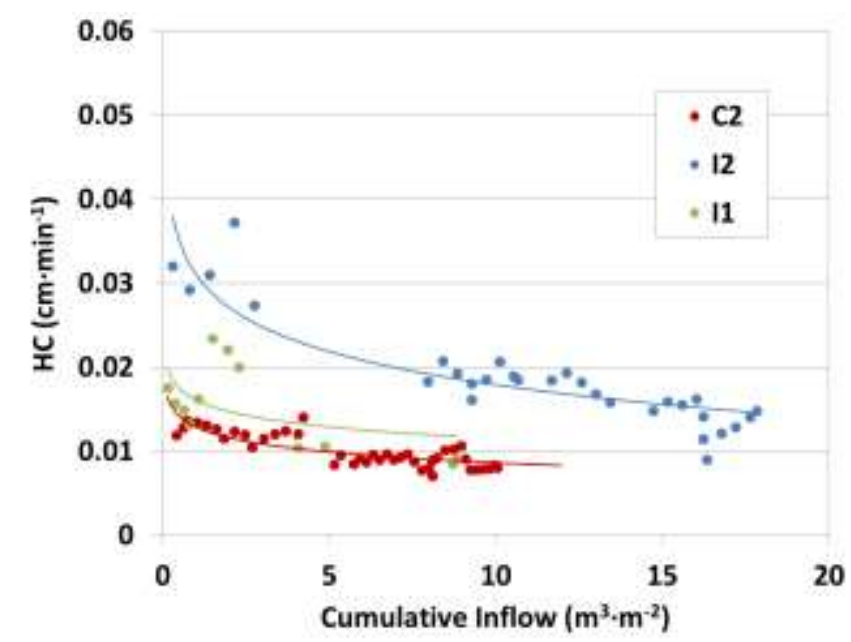

Fig. 4. Evolution of hydraulic conductivities for the three columns on cumulative load.

As already mentioned, several phenomena can affect soil HC: physical clogging due to SS filtration, biological clogging (consequence of organic matter degradation), chemical clogging in particular clay swelling and dispersion. To discern the driving mechanism, physical and chemical parameters were taken into account.

$\mathrm{O}_{2}$ concentrations in the columns, gives information on oxic and anoxic conditions, and can used to determine saturated or unsaturated conditions in the soil. Fig. 5 shows $\mathrm{O}_{2}$ concentration changes for the continuously fed column (C2) and the intermittently fed column (I2) during a selected period of 16 days. Initial conditions and total hydraulic loads of the two columns are comparable for this 
period. For column $\mathrm{C} 2$, after about 8 days of operation a permanent ponding was observed on the surface and after 10 days of operation column showed completely saturated conditions. The I2 column started to be completely saturated at the end of the feeding period; however during rest period column desaturation allowed $\mathrm{I} 2$ to completely recover oxic conditions. The pattern shown in Fig. 5 was observed for every feeding cycle for intermittent columns. Permanent ponding was sometimes observed at the end of the feeding period for intermittent columns. For the two intermittent columns, oxygen contents exhibit the same patterns. However because column I1 was less loaded, higher oxygen content within the first centimetres was observed during feeding period (results not shown). During rest period, desaturation was fast enough to insure sufficient oxic conditions after 1 - 2 days of rest. Therefore, for the last three cycles, rest periods were reduced to 3.5 days. This cadence gave good results in term of infiltration performers and $\mathrm{O}_{2}$ concentrations.

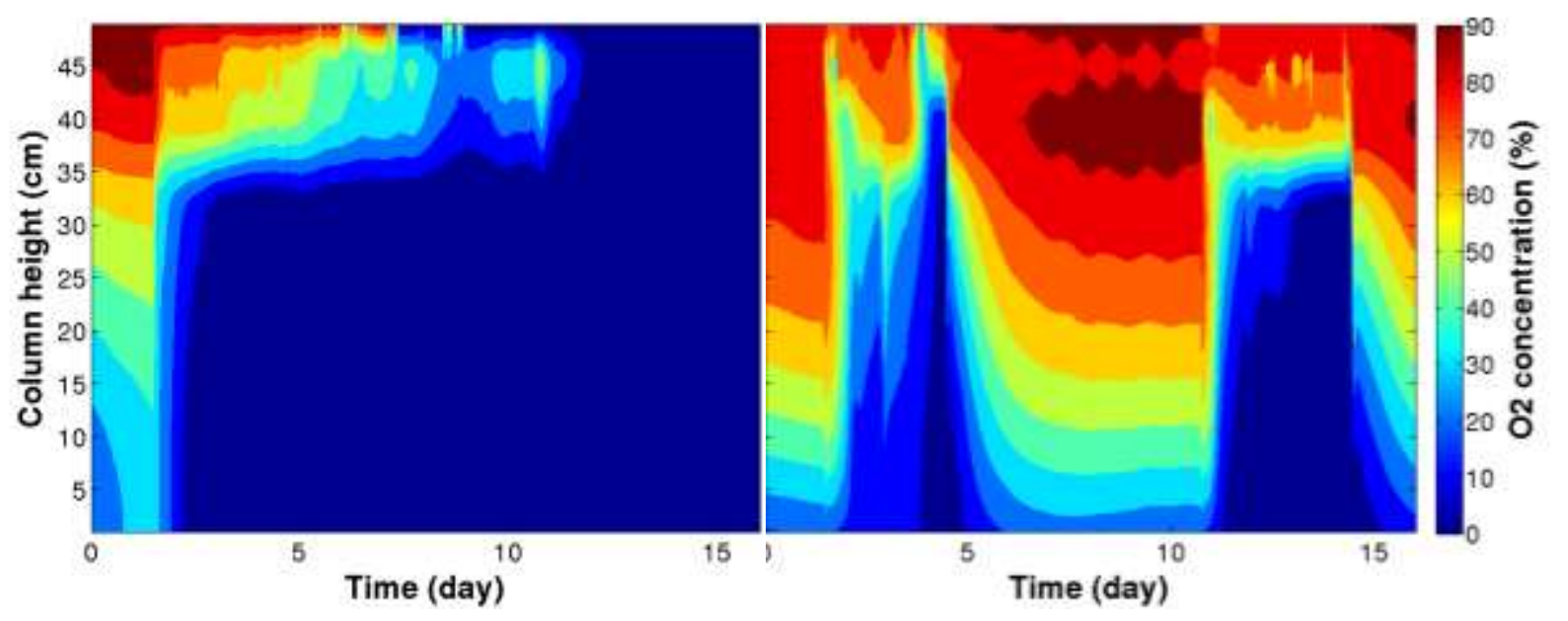

Fig. 5. Temporal evolution of dissolved oxygen in continuous column C2 (on the left) and intermittent column I2 (on the right) for 16 days. The oxygen concentrations are expressed as a percentage of the oxygen saturation (\%[O $\left.\mathrm{O}_{2}\right]$ sat) versus depth and time. Oxygen content profiles are established from 5 measurements, using spatial linear interpolation. 
The difference observed in term of saturation conditions of intermittent and continuous columns could explain the cumulative loads accepted by the columns, in particular in relation to clay behaviour. If clay swelling is present, during the desaturation phase water adsorb by clay could be partly released and induced a necessary swelling reduced.

\subsubsection{Treatment performances and soil geochemical behaviour}

Samples of the TWW used for the test were periodically taken from the four influent tanks. Concentrations were constant during the entire experiment, exception made of few episodes with high TOC and SS concentrations, as can be noticed in

Fig. 6. It might be caused by sludge losses from the clarifier.

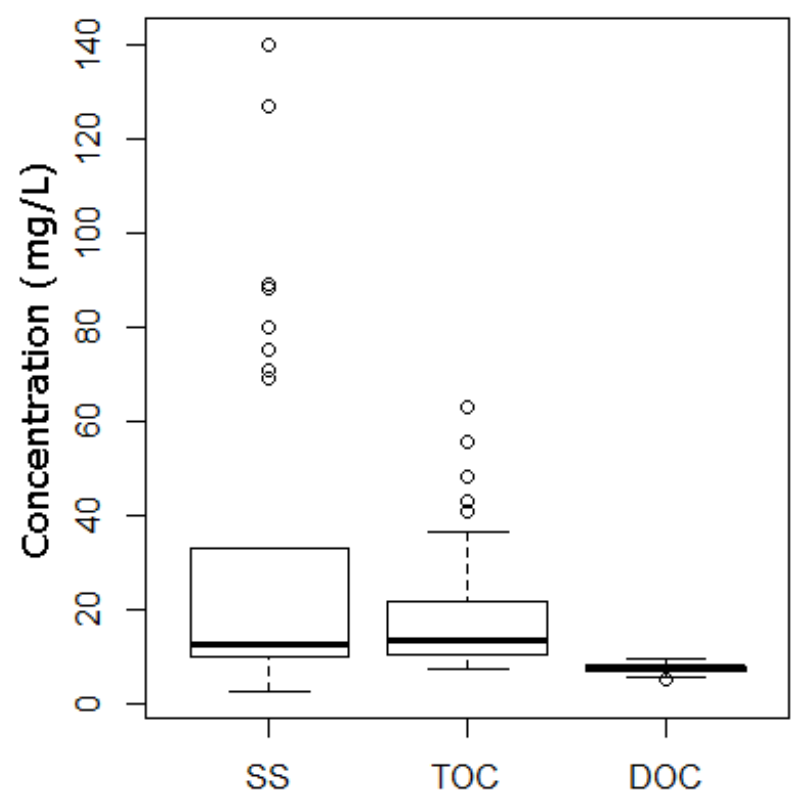

Fig. 6. SS, TOC and DOC concentrations of TWW used for infiltration tests experiments (inlet water). 
pH was between 7.2 and 8.0 and EC from 700 to $900\left(\mu \mathrm{S} \cdot \mathrm{cm}^{-1}\right)$. SAR adj and PAR were periodically calculated. SAR $\mathrm{adj}_{\mathrm{j}}$ ranged between 1.8 and 2.2 and PAR 0.2 and 0.3. Based on measured EC, these values did not correspond to a risk of infiltration capacity decrease. [37] However, as stated by Bennett and Raine [45], this parameter should be considered in relation with soil characteristics. Soils rich in clay may show infiltration capacity decrease even at low SAR and PAR. Indeed, the negative effects of $\mathrm{Na}^{+}$are more pronounced in presence of clay. In particular, because of the high percentage of expanding clays, the exchange between divalent and monovalent cations could have played an important role in the decrease of HC observed.

Analysis of inlet and outlet water (Fig. 7) showed that for most of the elements analysed in the first period of feeding, some geochemical changes took place. Later equilibrium conditions were reached and inlet and outlet concentrations were equivalent. Sulphates were released at the beginning with a trend comparable with $\mathrm{Ca}$ and $\mathrm{Mg}$. Dissolution of some mineral phase containing calcium sulphate and magnesium sulphate could explain this occurrence. Because of the studied backfill contains building material, we suspect the presence of sulphates phases as gypsum, even if their concentrations were not sufficient to be detected by XRD. At the beginning of the feeding, divalent cations $\left(\mathrm{Ca}^{2+}, \mathrm{Mg}^{2+}\right)$ were also released and monovalent cations $\left(\mathrm{K}^{+}, \mathrm{Na}^{+}\right)$retained, supporting the idea of a possible cation exchange with montmorillonite. Molar ratio between $\mathrm{Ca}^{2+}$, $\mathrm{Mg}^{2+}$ and sulphate confirms that both mechanism (mineral phase dissolution and cation exchange) could have played a role. The preferential affinity of montmorillonite clay for $\mathrm{Na}^{+}$over $\mathrm{Ca}^{2+}$ is well documented [21] and the occurrence of a cation exchange was predictable by the CEC measured. However the intensity of the exchange and the consequences could not be observed without infiltration experiments. It can be noticed that $\mathrm{K}^{+}$was retained but, differently from $\mathrm{Na}^{+}$, outflow concentrations of $\mathrm{K}^{+}$remained lower than inflows until the end of the experience. Phosphate was 
retained during the all experience and outlet concentrations with a maximum value of $0.54 \mathrm{mg} \cdot \mathrm{L}^{-1}$ and a mean of $0.12 \mathrm{mg} \cdot \mathrm{L}^{-1}$ of $\mathrm{PO}_{4}{ }^{3-}$.
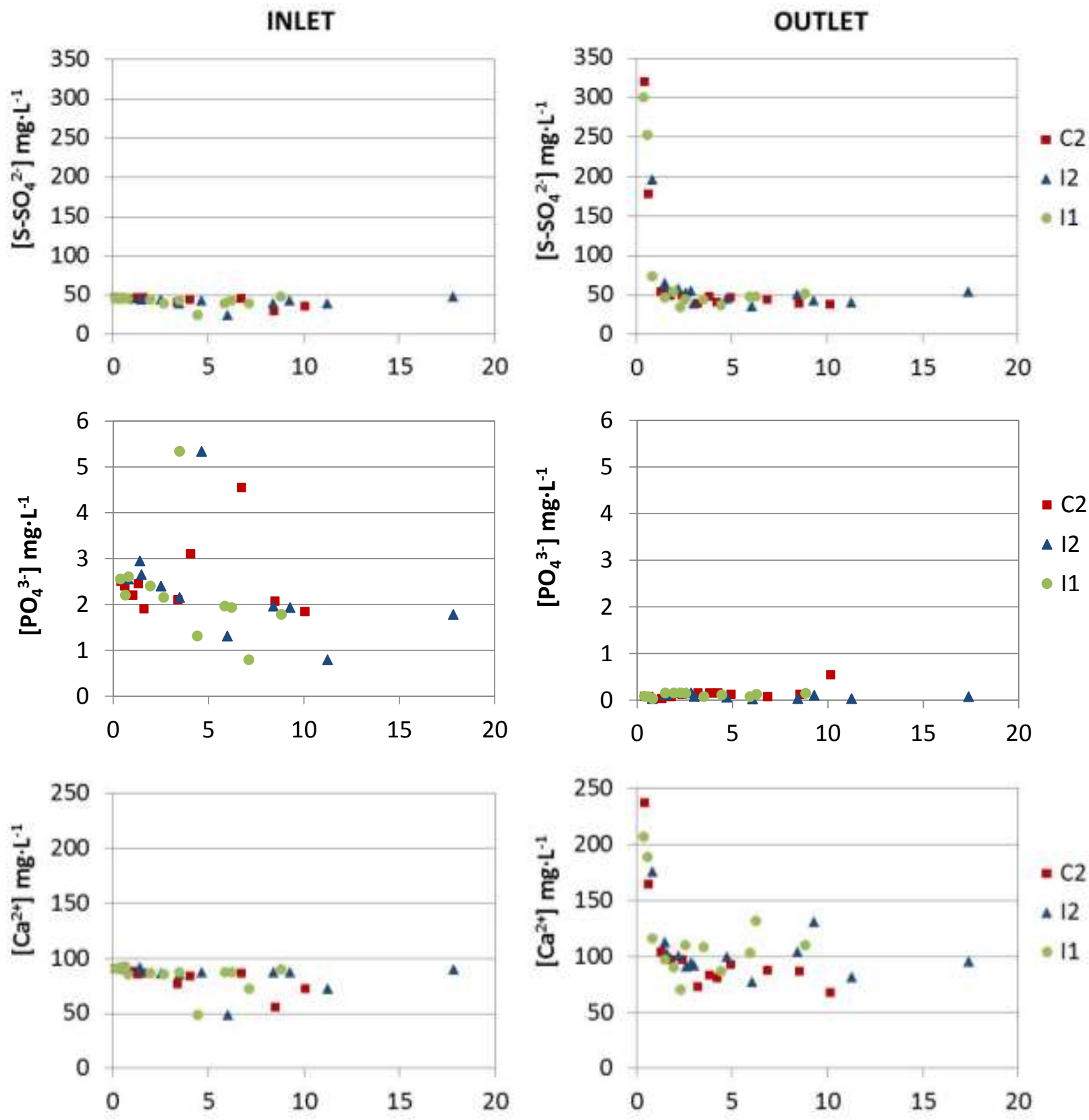

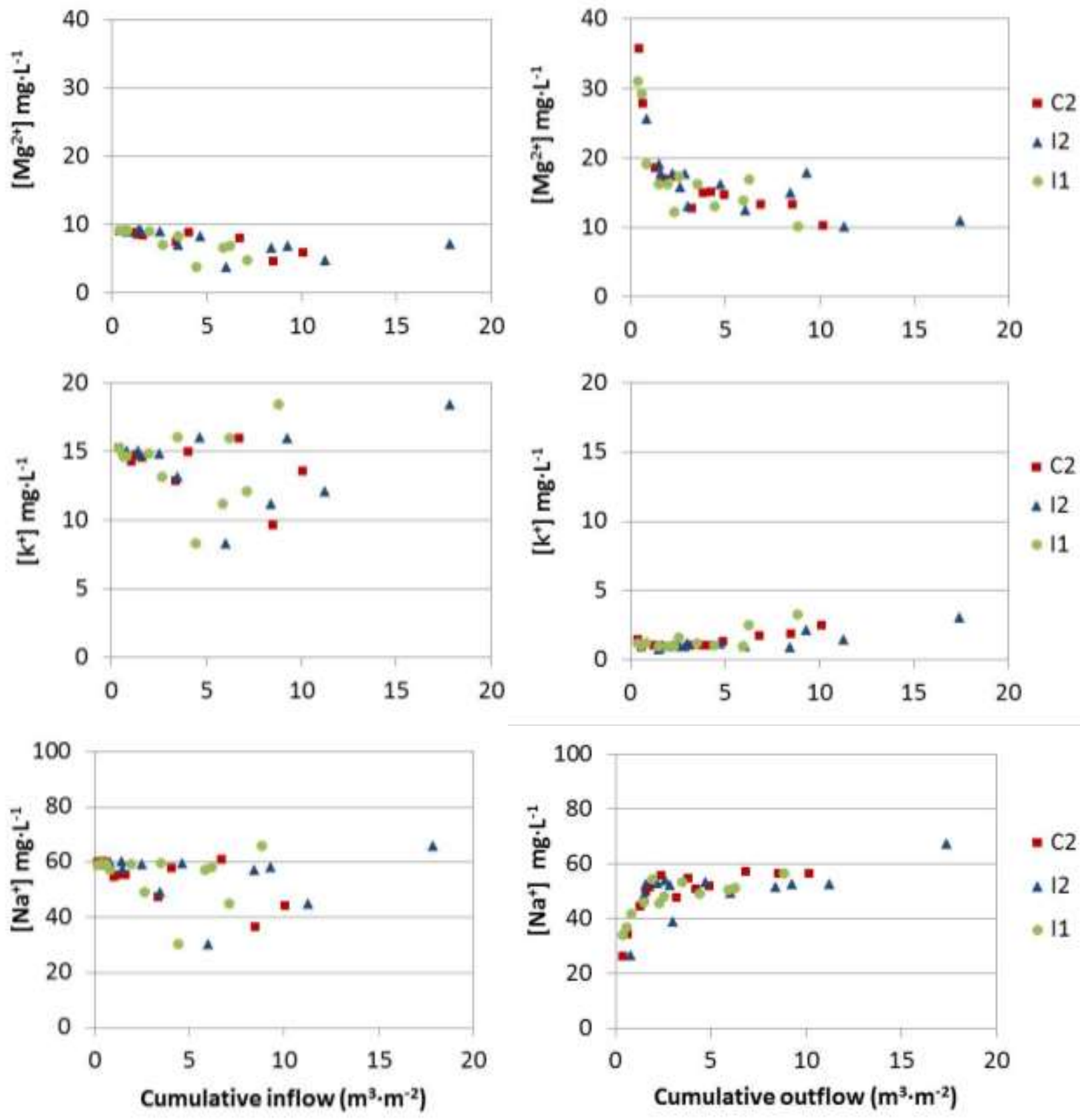

Fig. 7. Inflow and outflow water concentrations for major cations and anions in the three columns.

The exchange between mono and divalent cations, combined with the high presence of expanding clay had a major role to the swelling of clays, hence to the decrease of the porosity of the soil during feeding periods.

Decrease in $\mathrm{HC}$ has been largely documented for soil treatment unit and has been mostly attributed to physical and biological clogging. [2,19] However the water infiltrated in the documented 
treatment units has higher concentrations of SS and biodegradable organic carbon than the TWW used in this study.

Physical clogging by solids accumulation within the pores of the first centimetres of material would have led to an increase in the hydraulic gradient for identical ponding heights. Observations using the tensiometers at 1 and 5 centimetres allow computing this gradient and it did not significantly change over the course of the experiment for identical ponding heights. Therefore physical clogging within the first few centimetres seemed not to explain the diminution of the HC. SS deposition at the surface could also have led to physical clogging. However, SS concentrations of inlet water were low and the observed deposit was scarce and never fully covers the surface of the column. Nevertheless, we observed the formation of a crust due to the feeding by sprinkler that certainly decreased the HC. [46]

Bioclogging could result from organic carbon degradation, nitrification, denitrification or reduction of sulphur. DOC measured at the inlet equals the DOC at the outlet highlighting the low degradability of the influent. This was confirmed by SUVA measurements performed on samples collected by porous cup at different depths: aromaticity at 1, 10 and $19 \mathrm{~cm}$ depth were $22 \pm 1 \%$, $22 \pm 1 \%$ and $19 \pm 1 \%$ respectively. These results showed a poor degradation trend and a low degradability of the organic matter present in the TWW used. Mass-balance on nitrogen proved that little nitrification occurred in intermittent columns and that denitrification did not occur in any column. Sulphate concentrations at the inlet and outlet did not indicate any activity by sulphatereducing bacteria. Therefore bioclogging is unlikely to have caused $\mathrm{HC}$ decrease.

In conclusion, the mechanism that seemed to influence the most $\mathrm{HC}$ decrease was clay swelling. This could also explain why intermittent column were able to receive higher hydraulic loads. During rest period swelling reduces and the $\mathrm{HC}$ is partially restored, even if the free swelling of 
clay is not completely reversible [47] and clay can accumulated swelling after a wetting-dryingwetting cycles. [48]

Intermittent feeding mode allowed the acceptance of higher loading rates compared to continuous mode. Moreover, this mode has some advantages in term of performances. The importance of drying period for renewing of oxygen in the soil column was already pointed out by Guilloteau et al. [49] Infiltration basins in soil aquifer treatment systems are also intermittently feed to provide restoration of infiltration rates and soil aeration. [50] In this study no significant difference was observed on organic carbon degradation, in reverse a substantial difference was observed in nitrate concentrations. After rest period, an increase in nitrate concentration was observed in intermittent columns, sign of a nitrification supported by oxic conditions. Effect of nitrification on $\mathrm{NH}_{4}{ }^{+}$could not be observed as it is also adsorbed in soil and therefore outlet concentrations always remain low.

Beside the advantage of intermittent feeding on infiltration rate and soil oxygenation, changing between oxic and anoxic conditions in the near-surface layer could lead to redox modification. These variations could influence speciation of some elements and, as a consequence, induce alterations in contaminant retention. [15] This point is particularly important in the case of technosol which are frequently characterized by high level of contaminants as As, $\mathrm{Hg}$ or heavy metals. Longer experiment are needed to ensure the stability of soil retention, even so in this study no significant differences were observed between intermittent and continuous columns in term of water characteristic for major anions and cations as showed in Fig. 7 and phosphate.

\subsubsection{Phosphate retention}

During all experiment, outlet water concentrations of phosphates were close or under the detection limits for the four columns. By calculation on inlet and outlet water phosphate concentrations and 
water flow, it was estimated that during the entire experiment the column that received the higher hydraulic load (I2) cumulated $3.3 \mathrm{~g}$ of phosphorus. Total phosphorus $\left(\mathrm{P}_{\text {tot }}\right)$ in soil before infiltration tests had a concentration of $\mathrm{P}$ of $0.51 \mathrm{~g} \cdot \mathrm{kg}^{-1}$ of dried soil. $\mathrm{P}_{\text {tot }}$ was analysed after infiltration test in seven layers of column I2: 0 - 5; 5 - 10; 10 - 20; 20 - 30; $30-40 ; 40$ - 50 and $50-54 \mathrm{~cm}$. Fig. 8 shows $\mathrm{P}_{\text {tot }}$ concentrations in the column by depth. The near surface layer concentration of $\mathrm{P}$ was higher compared to the rest of the column and to soil before treatment. This can be partially due to accumulation of $\mathrm{P}_{\text {tot }}$ present in SS, but mostly ascribed to phosphate retention.

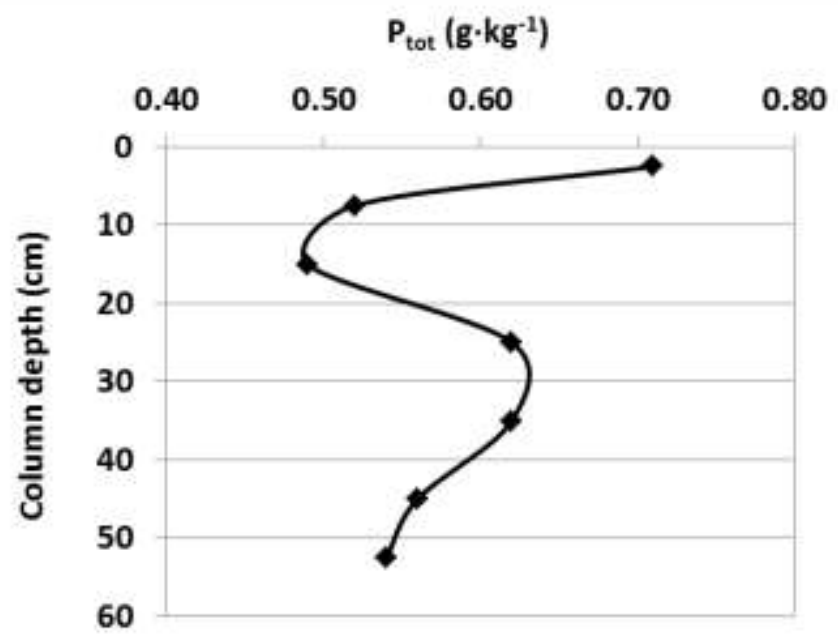

Fig. 8. $P_{\text {tot }}$ distribution in column I2 after infiltration test.

Since the experiment duration was limited, an isotherm of $\mathrm{P}$ adsorption was established to quantify the phosphorous retention capacity of the studied soil. Maximum adsorption of this soil was estimated equivalent to $590 \mathrm{mg} \cdot \mathrm{kg}^{-1}$ of dried soil. Langmuir isotherm experiment may provide a quick screen tool but it is necessary to evaluate $\mathrm{P}$ sorption of substrates to full-scale trials, moreover porosity of the media can decrease the availability of adsorption sites.

Knowing in which form $\mathrm{P}$ is retained is also important to understand and predict the stability of retention. Redox potential is a critical parameter, when reduction of iron $\mathrm{Fe}$ (III) to $\mathrm{Fe}(\mathrm{II})$ occurs 
the efficiency of $\mathrm{P}$ bounding is reduced, leading to a possible desorption. [26,51] Soil saturation could then influence phosphorus retention and desorption. In the limited time of the study no difference was observed between continuous and intermittent columns.

Sequential P fractionation could give more information about retention mechanism. Even though, a few hypotheses can be made on the basis of soil characteristics. Because of the high $\mathrm{pH}, \mathrm{P}$ retention could depend on calcium. The absence of release of $\mathrm{P}$ with change in oxic conditions could strengthen the hypothesis of an adsorption governed by Ca rather than Fe. Even if Kim et al. [28] observed that longer period of saturation are needed to observe P release. Moreover, the high presence of $\mathrm{Fe}$ in the soil makes the adsorption on Fe possible. Finally, clays could also have contributed to P retention. Bergaya et al. [24] reported a potential adsorption of $0.2-0.3 \mathrm{~mol} \cdot \mathrm{kg}^{-1}$ of phosphate by kaolinite and montmorillonite. A more recent review [44] gathered that phosphate sorption capacity of clay have been underestimated and rated adsorption capacities from 0.9 to 13 $\mathrm{mol} \cdot \mathrm{kg}^{-1}$ for montmorillonite and from 0.9 to $8 \mathrm{~mol} \cdot \mathrm{kg}^{-1}$ for illite.

\section{Conclusions and perspectives}

This study enabled to determine the more valuable loading mode for TWW infiltration in the studied soil. Despite a comparable decrease in $\mathrm{HC}$ for the four columns, the intermittent loading mode allowed a longer feeding and supported higher total loads. As expected from previous works, intermittent feeding proved to be favoured in term of infiltration and treatment performances, promoting nitrification. This works contributed to the identification of mechanism explaining the advantage of an intermittent feeding, in particular to decrease the impact of clay swelling. Results on Bègles soil showed that because of low salinity and SS of TWW, the possibility of use this kind of soil for soil-based constructed wetlands is not to exclude. 
The observation of re-oxygenation evolution of the soil column enabled to advice on feeding schedule. For the hydraulic load tested, a schedule of 3.5 days of feeding followed by 3.5 days of rests could be enough to ensure re-oxygenation of the soil and promote nitrification.

Analysis the main causes of clogging was also important to determine the most important parameters to monitor and plan larger scale tests. In that specific case cation exchange and consequent clay swelling was the main cause of $\mathrm{HC}$ decrease, this confirmed that soil characterization is an important element for soil-based constructed wetlands engineering.

The potential of $\mathrm{P}$ adsorption was confirmed. Saturation and desaturation cycles did not influence phosphate retention. More investigations are needed to estimate the durability and stability of $\mathrm{P}$ retention.

Results on this soil could be enlarged to other sites. Despite it is normally not recommended to use soils rich in clay for TWW infiltration, they could have some interesting characteristics in term of $\mathrm{P}$ retention which is one of the main objectives of a tertiary treatment. If loading rates can meet the requirements their utilization may be considered using intermittent loads.

Intermittent loads could lead to redox variations, and then influence the solubility of trace elements present in the soil. Redox conditions and trace elements concentrations in outlet water should be monitored in pilot experiments. 


\section{References}

[1] Lindbo D, Deal N, Anderson J, Gustafson D, Hart W, Hoover M, Lenning D, Loudon T, Mooers J. Model Decentralized Wastewater Practitioner Curriculum. Project No. WU-HT-01-05. Prepared for the National Decentralized Water Resources Capacity Development Project, Washington University, St. Louis, MO, by North Carolina State University, Raleigh, NC. 2005.

[2] McKinley JW, Siegrist RL. Soil Clogging Genesis in Soil Treatment Units Used for Onsite Wastewater Reclamation: A Review. Crit. Rev. Environ. Sci. Technol. 2011;41:2186-2209.

[3] Ollivier P, Surdyk N, Azaroual M, Besnard K, Casanova J, Rampnoux N. Linking water quality changes to geochemical processes occurring in a reactive soil column during treated wastewater infiltration using a large-scale pilot experiment: Insights into $\mathrm{Mn}$ behavior. Chem. Geol. 2013;356:109-125.

[4] Singh PK, Ladwani K, Deshbhratar PB, Ramteke DS. Impact of paper mill wastewater on soil properties and crop yield through lysimeter studies. Environ. Technol. 2013;34:599-606.

[5] Siegrist RL, Lowe KS, Geza M, Mccray JE. Soil Treatment Units Used for Effluent Infiltration and Purification within Onsite Wastewater Systems: Science and Technology Highlights. Southwest Onsite Wastewater Conference. Proceedings; Laughlin, Nevada; 2014.

[6] Siegrist RL. Engineering Design of a Modern Soil Treatment Unit. Innovations in Soil based Onsite Wastewater Treatment. Soil Society Society of America Conference. Proceeding; Albuquerque, NM; 2014.

[7] Laurence G. Willow Based Evapotranspiration Systems for the on-Site Treatment of Domestic. Wastewater in Areas of Low Permeability SubsoilsInnovations in Soil -based Onsite Wastewater Treatment. Soil Society Society of America Conference. Proceeding; Albuquerque, NM; 2014.

[8] Eveborn D, Gustafsson JP, Elmefors E, Yu L, Eriksson A-K, Ljung E, Renman G. Phosphorus in soil treatment systems: accumulation and mobility. Water Res. 2014;64:42-52. 
[9] ONEMA. Etat des lieux national des Zones de Rejet Végétalisées [National report on constructed wetland for treatet waste water]. 2013. http://www.onema.fr/IMG/pdf/2013_003.pdf

[10] Petitjean A, Forquet N, Choubert JM, Coquery M, Bouyer M, Boutin C. Land characterisation for soil-based constructed wetlands: adapting investigation methods to study goals. (In Press). Water Pract. Technol. 2015;10:660-668. .

[11] Carroll S, Goonetilleke A, Khalil WAS, Frost R. Assessment via discriminant analysis of soil suitability for effluent renovation using undisturbed soil columns. Geoderma. 2006;131:201217.

[12] Carroll S, Goonetilleke A, Dawes L. Framework for soil suitability evaluation for sewage effluent renovation. Environ. Geol. 2004;46:195-208.

[13] Bedbabis S, Ben Rouina B, Boukhris M, Ferrara G. Effect of irrigation with treated wastewater on soil chemical properties and infiltration rate. J. Environ. Manage. 2014;133:45-50.

[14] Jenssen PD, Siegrist RL. Two simple Methods for Estimating the Unsaturated Hydraulic Conductivity for Septic System Absorption Beds. In: On-site Wastewater Treatment. Fourth National Symposium on Individual and Small Community Sewage Systems. Proceeding; New Orleans, LA; 1984.

[15] Couture R-M, Charlet L, Markelova E, Madé B, Parsons CT. On-Off Mobilization of Contaminants in Soils during Redox Oscillations. Environ. Sci. Technol. 2015;49:3015-3023.

[16] Siegrist RL, Boyle WC. Wastewater Induced Soil Clogging Development. J. Environ. Eng. 1987;113:550-566.

[17] Van Cuyk S, Siegrist RL, Logan A, Masson S, Fischer E, Figueroa L. Hydraulic and purification behaviors and their interactions during wastewater treatment in soil infiltration systems. Water Res. 2001;35:953-964.

[18] Lowe KS, Siegrist RL. Controlled Field Experiment for Performance Evaluation of Septic Tank Effluent Treatment during Soil Infiltration. J. Environ. Eng. 2008;134:93-101. 
[19] Beach DNH, McCray JE, Lowe KS, Siegrist RL. Temporal changes in hydraulic conductivity of sand porous media biofilters during wastewater infiltration due to biomat formation. J. Hydrol. 2005;311:230-243.

[20] Chaudhari SK, Somawanshi RB. Unsaturated flow of different quality irrigation waters through clay, clay loam and silt loam soils and its dependence on soil and solution parameters. Agric. Water Manag. 2004;64:69-90.

[21] Buelow MC, Steenwerth K, Parikh SJ. The effect of mineral-ion interactions on soil hydraulic conductivity. Agric. Water Manag. 2015;152:277-285.

[22] Reddy KR, Kadlec RH, Flaig E, Gale PM. Phosphorus Retention in Streams and Wetlands: A Review. Crit. Rev. Environ. Sci. Technol. 1999;29:83-146.

[23] Kim B, Gautier M, Rivard C, Sanglar C, Michel P, Gourdon R. Effect of Aging on Phosphorus Speciation in Surface Deposit of a Vertical Flow Constructed Wetland. Environ. Sci. Technol. 2015;49: 4903-4910.

[24] Bergaya F, Lagaly G, Vayer M. Chapter 12.10, Cation and anion exchange. In: Bergaya F, Theng BKG, Lagaly G. Handbook of clay science. Vol. 1. Amsterdam: Esevir; 2006. p. 979-1001.

[25] Xu D, Xu J, Wu J, Muhammad A. Studies on the phosphorus sorption capacity of substrates used in constructed wetland systems. Chemosphere. 2006;63:344-352.

[26] Oxmann JF, Schwendenmann L. Authigenic apatite and octacalcium phosphate formation due to adsorption-precipitation switching across estuarine salinity gradients. Biogeosciences. 2015;12:723-738.

[27] Sato S, Comerford NB. Influence of soil $\mathrm{pH}$ on inorganic phosphorus sorption and desorption in a humid Brazilian Ultisol. Rev. Bras. Cienc. do Solo. 2005;29:685-694.

[28] Kim B, Gautier M, Molle P, Michel P, Gourdon R. Influence of the water saturation level on phosphorus retention and treatment performances of vertical flow constructed wetland combined with trickling filter and $\mathrm{FeCl} 3$ injection. Ecol. Eng. 2015;80:53-61. 
[29] Dunets CS, Zheng Y. Removal of phosphate from greenhouse wastewater using hydrated lime. Environ. Technol. 2014;35:2852-2862.

[30] Baize D, Girard M-C. Référentiel pédologique 2008. Editions Q. Savoir Faire. Versailles (France); 2008.

[31] Thiry M, Carrillo N, Franke C, Martineau N. Technique de préparation des minéraux argileux en vue de l'analyse par diffraction des Rayons $\mathrm{X}$ et introduction à l'interprétation des diagrammes. Fontainebleau, France: Centre de géosciences. Ecole des mines de Paris; 2013.

[32] Bromly M, Hinz C, Aylmore L a G. Relation of dispersivity to properties of homogeneous saturated repacked soil columns. Eur. J. Soil Sci. 2007;58:293-301.

[33] Lewis J, Sjöstrom J. Optimizing the experimental design of soil columns in saturated and unsaturated transport experiments. J. Contam. Hydrol. 2010;115:1-13.

[34] John, Huber. Instruction Manual. OXY-10. 10-Channel fiber-Optic Oxygen Meter. Regensburg (Germany): PreSens; 2005.

[35] Petitjean A, Forquet N, Boutin C. Oxygen Transfer and Clogging in Vertical Flow Sand Filters for on-site Wastewater Treatment. J. Environ. Manage. 2016;3:1-6.

[36] Morvannou A, Forquet N, Michel S, Troesch S, Molle P. Treatment performances of French constructed wetlands: results from a database collected over the last 30 years. Water Sci. Technol. 2015;71:1333-1339.

[37] Asano T, Burton F, Leverenz H, Tsuchihashi R, Tchobanoglous G. Water reuse: issues, technologies, and applications. McGraw-Hill New York; 2007. Chapter 17; Agricultural Uses of Reclaimed Water; p. 954-970.

[38] Soares-pereira C, Matar Z, Bonnot C, Guo Y, Parlanti E, Gelabert A, Cordier L, Tharaud M. Matière organique: sources, caractérisation et rôle dans la biogéochimie des contaminants [Organic matter: Origin, characterization and role in the bio-geochemical of contaminants]. Colloque PIREN-Seine 2013. Proceeding; 2013; Paris. 
[39] van de Graaff R, Patterson RA. Explaining the Mysteries of Salinity, Sodicity, SAR and ESP in on-Site Practice. On-site '01. Advancing On-site Wastewater Systems. Proceeding; Armidale: Lanfax Laboratories; 2001. p. 361-368.

[40] Abel CDT, Sharma SK, Buçpapaj E, Kennedy MD. Impact of hydraulic loading rate and media type on removal of bulk organic matter and nitrogen from primary effluent in a laboratoryscale soil aquifer treatment system. Water Sci. Technol. 2013;68:217-226.

[41] Bergaya F, Lagaly G. General introduction: clays, clay minerals and clay science. In: Bergaya F, Theng BKG, Lagaly G. Handbook of clay science. Vol. 1. Amsterdam: Elsevir; 2006; pp. 1-18.

[42] Aksu I, Bazilevskaya E, Karpyn ZT. Swelling of clay minerals in unconsolidated porous media and its impact on permeability. GeoResJ. 2015;7:1-13.

[43] Gautier M, Muller F, Le Forestier L, Beny J-M, Guegan R. NH4-smectite: Characterization, hydration properties and hydro mechanical behaviour. Appl. Clay Sci. 2010;49:247-254.

[44] Gérard F. Clay minerals, iron/aluminum oxides, and their contribution to phosphate sorption in soils - A myth revisited. Geoderma. 2016;262:213-226.

[45] Bennett JM, Raine SR. The soil specific nature of threshold electrolyte concentration analysis. 5th Joint Australian and New Zealand Soil Science Conference. Proceeding; Hobart, Australia. 2012.

[46] Le Bissonnais Y, Le Souder C. Mesurer la stabilité structurale des sols pour évaluer leur sensibilité à la battance et à l'érosion [Measurement of structural stability of soils to evaluate their sensibility to erosion]. Etude Gest. des Sols. 1995;2:43-56.

[47] Wang LL, Bornert M, Héripré E, Yang DS, Chanchole S. Irreversible deformation and damage in argillaceous rocks induced by wetting/drying. J. Appl. Geophys. 2014;107:108-118.

[48] Chen R, Ng CWW. Impact of wetting-drying cycles on hydro-mechanical behavior of an unsaturated compacted clay. Appl. Clay Sci. 2013;86:38-46. 
[49] Guilloteau J a., Lesavre J, Lienard a., Genty P. Wastewater treatment over sand columns Treatment yields, localisation of the biomass and gas renewal. Water Sci. Technol. 1993;28:109116.

[50] Pescod MB. Wastewater treatment and use in agriculture - FAO irrigation and drainage paper 47. 1992. Available from: http://www.fao.org/documents/card/en/c/b97b5665-69d7-5141b0be-d6765724c56a/

[51] Sundareshwar P V., Morris JT. Phosphorus sorption characteristics of intertidal marsh sediments along an estuarine salinity gradient. Limnol. Oceanogr. 1999;44:1693-1701. 